\title{
Potentiality of income generation through Non-timber Forest Products: A case study from the Sallipatan Trishakti Community Forest, Bajhang district, Nepal
}

Jeewan Singh ${ }^{1}$, Mahamad Sayab Miya ${ }^{2 *}$, Amit Adhikari ${ }^{3}$, Lalit Kumar Lal Das ${ }^{4}$

1,4 Tribhuvan University, Institute of Forestry, Hetauda Campus, Hetauda, Nepal

2, 3 Tribhuvan University, Institute of Forestry, Pokhara Campus, Pokhara, Nepal

sjeewan44@gmail.com¹, amitadhikari944@gmail.com³ ${ }^{3}$ lalit.laldas@yahoo.com

*Corresponding author: sayabmiya13@gmail.com

Received: March 05, 2021; Revised \& Accepted: March 18, 2021; Published: June 30, 2021 (C) Copyright: Miya (2021).

\begin{abstract}
Non-timber Forest Products are the major source of livelihood support for rural communities in Nepal. A case study was performed to determine the potentiality of income generation through Non-timber Forest Products (NTFPs) in the Sallipatan Trishakti community forest of Bajhang district, Nepal from February to April 2020. The Questionnaire surveys, key informant surveys, focus group discussions and forest resource inventory have been used for the data collection. A total of 37 species of NTFPs from 31 families were identified out of which only five species were found to have high market potential. Xanthoxylum armatum (Timur), Phyllanthus emblica (Amala), and Cinnamomum tamala (Tejpat) were found in good frequency and have a good market but the yearly earnings and the number of households involved were low. Bergenia ciliate (Pakhanbed), Valeriana jatamansi (Sugandhawal), and Rhododendron arboretum (Lali gurans) were present in high density in the forest and have high market value but locals didn't prefer and market them due to lack of knowledge and processing technology. Among the total respondents, 59\% collect NTFPs for household purposes, 30\% for selling purposes, and 11\% for traditional uses. Pinus roxburghii, Myrica esculenta, Swertia chirayita, Rhododendron arboretum, Cinnamomum tamala, Drepanostachyum sps., Asparagous racemous and Taxus wallichiana would have the potentiality for small scale business from the community forest if they were promoted and managed properly.
\end{abstract}

Keywords: Cinnamomum tamala, MAPs, NTFPs, Phyllanthus emblica, Xanthoxylum armatum, 


\section{INTRODUCTION}

All the products which may be derived from the forest other than the timbers are Nontimber forest products (NTFPs); also known as minor forest products (Ahenkan and Boon, 2011). NTFPs are broadly divided into two groups; consumptive (can be used directly) and nonconsumptive (have indirect benefits). They comprise medicinal and aromatic plants (MAPs), bamboo, rattan, papers, dyes, wild foods, soap, detergents, resin, fibers, and others (Hammet, 2004). The diverse geographic and climatic conditions within small areas result in a wide range of biodiversity richness in Nepal. About 11,971 flora are recorded from Nepal which accounts for $3.2 \%$ of the total flora in the world (GON, 2014). Nepal is very rich in NTFPs; about 700 plants are used as medicine, 440 plants as wild food, 30 plants as spices, and 71 plants as fibers (Subedi et al., 2014). Forest regulation (1995) has categorized NTFPs into eight different categories; fruits and seeds (65), roots and rhizomes (48), leaves/stem (30), bark (25), the whole plant (21), flower and fur (16), gum, resin and lac (8), and others (24) in Nepal (GoN/MoFSC, 1995). People use the NTFPs in various ways such as medicine, nutrition, forage, energy, fibers, resins, and oils (FAO, 1991).

NTFPs have a significant role in sustaining rural livelihoods, poverty alleviation, and economic growth of rural communities worldwide (Giri et al., 2001; Angelsen et al., 2014; Shackleton and Pullanikkatil, 2018; Reta et al., 2020). They have a potential capability to ensure food insecurity and reduce malnutrition in indigenous rural communities (Shrestha, 2020). In Nepal, about $80 \%$ of the rural population depends on the NTFPs to sustain their livelihood The NTFPs sub-sector contributes $5 \%$ of the national GDP out of the $15 \%$ contribution from the forestry sector (Pyakurel and Baniya, 2011). ANSAB (Asia Network for Sustainable Agriculture and Bioresources) has reported that around 189,000 are employed in this sub-sector drawing between 15 and 50\% of their household income (Karki and Bhattarai, 2012; MSFP, 2014). Department of Forest (2016) stated that $6.56 \%$ of the royalty from the forest sector was contributed from NTFPs. About 150 NTFPs are traded in the international market from Nepal (Shrestha et al., 2020). Roughly 10,000-15,000 tons of NTFPs (more than 100 species) are harvested and traded to the Indian and overseas markets drawing around US\$ 8.6 million annually (Edward, 1996). NTFPs sub-sector can create an opportunity for job employment and income-raising opportunities for those local people; reducing youth migration for jobs (Karki and Bhattarai, 2012).

Master Plan for Forestry Sector (1988) had given priority to revenue generation through NTFPs. The Forest Sector Policy (2015) also focuses on NTFPs to contribute to the rural livelihood and emphasized their research and study (MoFSC, 2015). There are very little researches in Nepal concerning the potential of NTFPs in community forests and no such research has been made at the study site. Hence, this study aims to determine the potentiality of income generation through NTFPs to the livelihoods of the local people and to rank the five most 
important NTFPs according to income generation potentiality and the user's preferences in the community forest.

\section{MATERIALS AND METHODS}

\section{Study area}

The study was conducted in the Bajhang district of Nepal (N 29 $29^{\prime}$ to $30^{\circ} 9^{\prime}$ and E $80^{\circ} 46^{\prime}$ to $81^{\circ} 34^{\prime}$ ) from February to April 2020. It extends over 3,42,200 hectare area between altitude ranges of $915 \mathrm{~m}$ to $7035 \mathrm{~m}$ (from sub-tropical to alpine) in Far-Western Province (Dhurba Bijaya et al., 2020; Sing et al., 2020). The study was mainly focused on Sallipatan Trishakti Community Forest. The CF is located in wards number 4 and 5 of Jayaprithvi Municipality; north of the Khaptad National Park. The CF lies in a rolling terrain covering an area of 610.43 hectares and was formulated in 2061/03/18. The Community Forest User Group (CFUG) comprises 282 households. The ethnic composition consists of Chhetri (major), Brahmin, Thakuri, Dalit, and other groups. The major tree species found in the forest are Phyllanthus emblica (Amala), Rhododendron arboretum (Lali gurans), Quercus thomsonian (Phalant), Myrica esculenta (Kafal), Pinus roxburghii (Khote salla), Alnus nepalensis (Uttis), and Toona ciliate (Tooni).

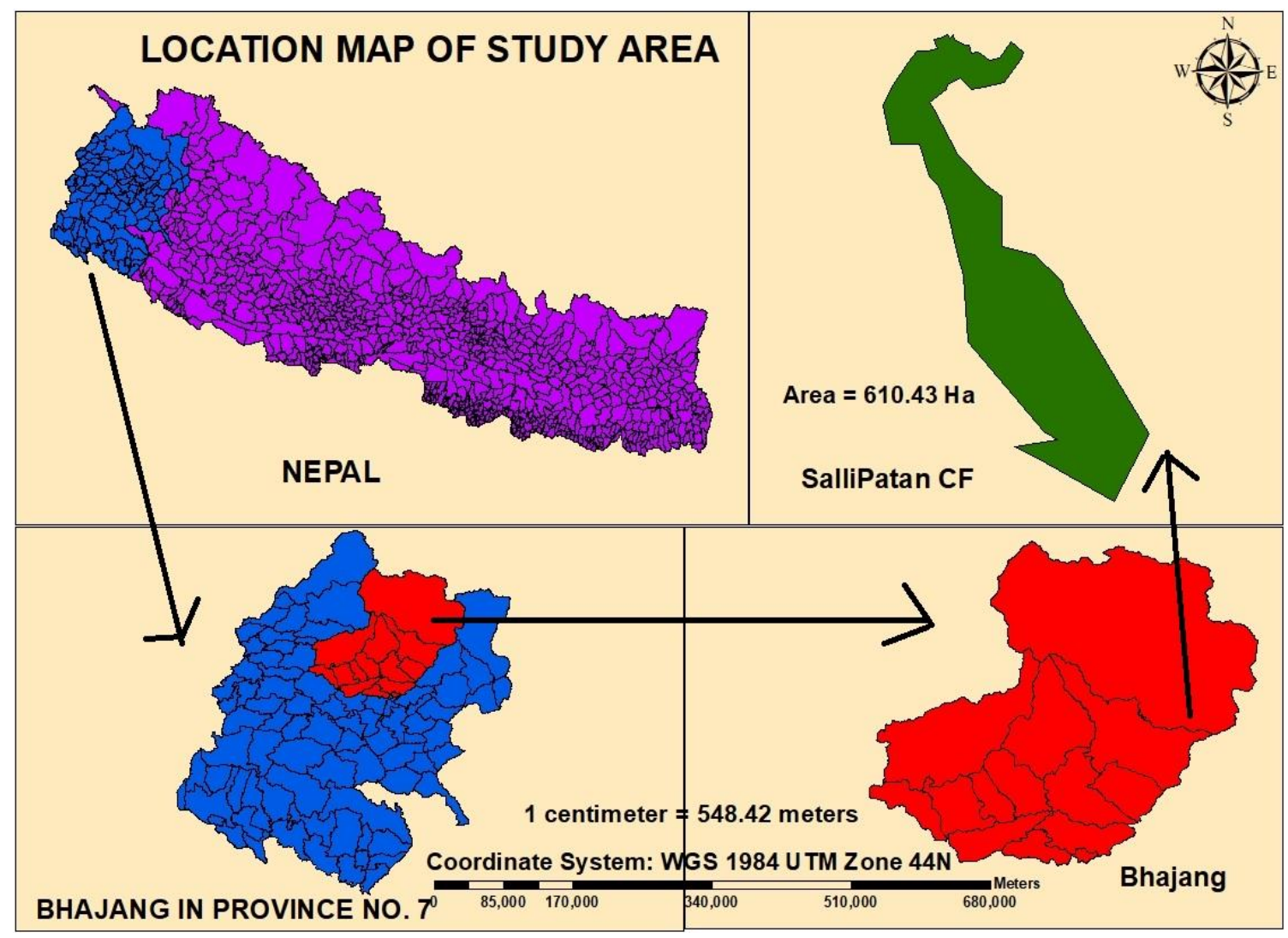

Figure 1: Map of the study area 


\section{Data collection}

The primary data were collected through a questionnaire survey, semi-structured interview, focus group discussion (FGD), direct observation, participatory resource mapping, and preference ranking. A total of 28 Households selected randomly were taken for the questionnaire survey. Out of which, 14 households were represented by males and 14 households represented by females. It helped to get a glimpse of the socio-economic status of the users, a listing of the NTFPs, their uses, status, existing income-generating activities based on NTFPs, and preference ranking of prioritized NTFPs with the set criteria. Key informants' interview was carried out with the local forest ranger, leader, teachers, elders, and executive committee members to get information about the NTFPs resources, their existing condition and uses. FGD was carried out with the CFUG during their annual general assembly. Also, participatory resource mapping was carried out during the FGD to assess and list the NTFPs in the study area. Matrix Preference and Pairwise Ranking was carried out for the selection of the prioritized species and potential of income generation. Matrix ranking was carried out by assigning value using the Likert scale against particular characteristics of potential NTFPs. The Pairwise ranking procedure was worked by maintaining a name of more preferred NTFPs in a cell out of two compared species. The secondary data were collected from published and unpublished documents, articles, and reports which were assessed through Google scholar and Research gate (Gautam et al., 2020; Miya et al., 2020; Timilsina et al., 2020).

\section{Data analysis}

The data were pooled and analyzed with SPPS software. The matrix preference ranking was done based on Matrix preferences ranking criteria (Table 1) for the potentiality of income generation.

Table 1: Matrix preferences ranking criteria

\section{S.N. Criteria}

\section{Scale/Value}

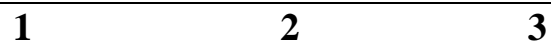

\section{Economy/Market}

a. Market demand

b. Profit

2. Ecology/Environment

a. Availability (in time)

b. Availability (in space)

c. Time needed to find and harvest

d. Impact of harvesting on survival of the species

e. Regenerative potential

Low

Low

Moderate

High

Moderate

High

Seasonal

Low

Long

High

Occasional

Always

Moderate

Widespread

Moderate Short

Moderate

Minimum

Low

Moderate

High

3. Social/Institutional

a. Contribution to income

Low

Moderate

High 


\begin{tabular}{|c|c|c|c|c|}
\hline b. & $\begin{array}{l}\text { Potential for income generation/ } \\
\text { employment }\end{array}$ & Low & Moderate & High \\
\hline c. & $\begin{array}{l}\text { Equal Benefit distribution to the } \\
\text { community }\end{array}$ & Limited & Reasonable & Well \\
\hline d. & Women's participation in business and use & Only men & Both & Only women \\
\hline e. & Uses & Single-use & Medium & Diverse \\
\hline 4. & Science/Technology & & & \\
\hline a. & Processing technology & Sophisticated & Mechanical & Manual/local \\
\hline b. & $\begin{array}{l}\text { Expertise needed for using processing } \\
\text { technology }\end{array}$ & Low & Moderate & High \\
\hline
\end{tabular}

(Source: Thakur, 2005; Danekhu et al., 2018)

If the range of average rank of the top five NTFPs falls within 0-1.5, it is low potential, and it is medium and high if falls within 1.5-2.5 and >2.5 respectively. The average rank of each top five NTFPs is calculated by dividing the sum of criteria ranking for each NTFP by the number of criteria.

\section{RESULTS}

A total of 37 species of NTFPs from 31 families has been recorded in the present study. The scientific name, local name, family name, and their local uses are given in Table 1. Only five NTFPs (Phyllanthus emblica, Justicia adhatoda, Zanthoxylum armatum, Cinnamomum tamala and Juglans regia) were the most market potential and more easily available NTFPs which were examined using the matrix ranking (Table 3). A pairwise ranking of these five species was carried out based on resource availability, local uses, and the market separately and the results are presented in Table 4 . The highest number of species were used for medicinal purposes (24 species) followed by food purposes (16 species). Families- Asteraceae (three species) and Poaceae (three species) represented the higher number of species followed by Lauraceae (two species) and Urticaceae (two species).

Table 2: NTFPs of Sallipatan Trishakti CF and their local uses

\begin{tabular}{lllll} 
S.N. & Scientific Name & Local Name & Family name & Local Uses \\
\hline 1. & Agaricus biosporus & Chyau & Agaricaceae & Medicine, food \\
2. & Allium wallichi & Ban Lasun & Amaryllidaceae & Food/Spice \\
3. & Alnus nepalensis & Uttis & Betulaceae & Medicine \\
4. & Artemisia indica & Titepati & Asteraceae & Medicine \\
5. & Bambusa sps. & Bans & Poaceae & $\begin{array}{l}\text { Making daily use products like } \\
\text { a basket. }\end{array}$ \\
6. & Berberis ariststa & Chutro & Berberidaceae & Medicine \\
7. & Bergenia ciliata & Pakhanbed & Saxifragaceae & Medicine for urinary stone
\end{tabular}


8. Cinnamomun tamala Tejpat

9. Coriaria nepalensis Machaino

10. Cynodon dactylon

11. Diplokenema

butyreace

12. Drepanostachyum sps.

13. Dryoathyrium boryanum

14. Dryopteris filix-mas

15. Eclipta prostrata

16. Eupatorium adenophorum

17. Girardinia diersifolia Aaloo

18. Juglans regia

19. Justicia adhatoda

20. Lichen $s p$.

21. Mentha arvensis

22. Moringa olifera

23. Myrica esculenta

24. Oxalis corniculata

25. Persea odoratissima

26. Phyllanthus emblica

27. Pinus roxburghii

28. Piper Longum

29. Rhododendron arboretum

30. Rubus ellipticus

31. Sapindus mukorossi
Lauraceae

Coriariaceae

Poaceae

Sapotaceae

Nigalo

Kali Neuro

Neuro/Fern

Bhirangaraj

Banmara

Okhar

ashuro

Jhyau

Pudina

Setak Chini

Kaphal

Charimilo

Kaulo

Amala

Khote salla

Pipli

Lali gurans

Ainselu

Ritho

Poaceae

Pteridaceae

Asteraceae

Asteraceae

Urticaceae

Juglandaceae

Acanthaceae

Parmeliaceae

Lamiaceae

Moringaceae

Myricaceae

Oxalidaceae

Lauraceae

Pinaceae

Piperaceae

Ericaceae

Rosaceae

Sapindaceae
Food

Dryopteridaceae Food

Medicine, oil for hair medicine

Bio briquette (fuel), Medicine (juice cuts and wounds)

Medicine

Phyllanthaceae
Food

Medicine

Medicine

Medicine, Aesthetic value

Spice, Medicine (stomach and breath problems)

Medicine

Food, Medicine (Bark for stomach ailments)

Medicine, Dye, Food

Used for the adhesive purpose

Food, Medicine (leaves for

Stomach and Skin diseases)

Resin, Medicine, turpentine

Fruit, Spice

Food, Medicine

Used in manufacturing of soap 


\begin{tabular}{|c|c|c|c|}
\hline Swetia chirayita & Chiraito & Gentianaceae & $\begin{array}{l}\text { Medicine (fever and bile } \\
\text { problems) }\end{array}$ \\
\hline Taxus wallichiana & Lauth Salla & Taxaceae & Medicine (for cancer patients) \\
\hline Tinospora sinensis & Gurjo & Menispermaceae & Medicine \\
\hline Urtica dioca & Sisnu & Urticaceae & Food, Medicine \\
\hline Valeriana jatamansi & Sughandawal & Caprifoliaceae & Scented oil \\
\hline $\begin{array}{l}\text { Zanthoxylum } \\
\text { armatum }\end{array}$ & Timur & Rutaceae & Spice \\
\hline
\end{tabular}

Table 3: Matrix ranking of Prioritized NTFPs

\begin{tabular}{|c|c|c|c|c|c|c|}
\hline \multirow{2}{*}{ S.N. } & \multirow{2}{*}{ Criteria } & \multicolumn{5}{|l|}{ Species } \\
\hline & & Amala & Ashuro & Timur & Tejpat & Okhar \\
\hline 1. & Economy/Market & & & & & \\
\hline a. & Market demand & 3 & 1 & 3 & 2 & 2 \\
\hline b. & Profit & 2 & 1 & 3 & 2 & 3 \\
\hline 2. & Ecology/Environment & & & & & \\
\hline a. & Availability (in time) & 1 & 3 & 1 & 2 & 1 \\
\hline b. & Availability (in space) & 1 & 3 & 1 & 1 & 2 \\
\hline c. & Time needed to find and harvest & 3 & 3 & 2 & 2 & 3 \\
\hline d. & $\begin{array}{l}\text { Impact of harvesting on the } \\
\text { survival of species }\end{array}$ & 3 & 3 & 3 & 3 & 3 \\
\hline e. & Regenerative potential & 3 & 1 & 3 & 1 & 2 \\
\hline 3. & Social/Institutional & & & & & \\
\hline a. & Contribution to income & 2 & 1 & 2 & 2 & 2 \\
\hline b. & $\begin{array}{l}\text { Potential for income } \\
\text { generation/employment }\end{array}$ & 3 & 2 & 3 & 3 & 3 \\
\hline c. & $\begin{array}{l}\text { Equal Benefit distribution to } \\
\text { community }\end{array}$ & 2 & 2 & 2 & 2 & 2 \\
\hline d & $\begin{array}{l}\text { Women's participation in business } \\
\text { and use }\end{array}$ & 2 & 3 & 2 & 2 & 3 \\
\hline e. & Uses & 3 & 3 & 2 & 2 & 1 \\
\hline 4. & Science/Technology & & & & & \\
\hline a. & Processing technology & 3 & 3 & 3 & 3 & 3 \\
\hline b. & $\begin{array}{l}\text { Expertise needed for using } \\
\text { processing technology }\end{array}$ & 1 & 1 & 1 & 1 & 2 \\
\hline & Total & 32 & 30 & 31 & 28 & 37 \\
\hline & Average (total/no. of criteria) & 2.28 & 2.14 & 2.21 & 2 & 2.64 \\
\hline
\end{tabular}


Table 4: Pairwise ranking of Prioritized NTFPs

1.On the basis of resource availability

\begin{tabular}{|c|c|c|c|c|c|}
\hline Species & Amala & Ashuro & Timur & Tejpat & Okhar \\
\hline Amala & Amala & Ashuro & Amala & Amala & Amala \\
\hline Ashuro & Ashuro & Ashuro & Ashuro & Ashuro & Ashuro \\
\hline Timur & Amala & Ashuro & Timur & Tejpat & Okhar \\
\hline Tejpat & Amala & Ashuro & Tejpat & Tejpat & Okhar \\
\hline Okhar & Amala & Ashuro & Okhar & Okhar & Okhar \\
\hline \multicolumn{6}{|c|}{ 2.On the basis of market availability } \\
\hline Species & Amala & Ashuro & Timur & Tejpat & Okhar \\
\hline Amala & Amala & Amala & Amala & Amala & Amala \\
\hline Ashuro & Amala & Ashuro & Timur & Tejpat & Okhar \\
\hline Timur & Amala & Timur & Timur & Timur & Timur \\
\hline Tejpat & Amala & Tejpat & Timur & Tejpat & Okhar \\
\hline Okhar & Amala & Okhar & Timur & Okhar & Okhar \\
\hline \multicolumn{6}{|c|}{ 3.On the basis of local use } \\
\hline Species & Amala & Ashuro & Timur & Tejpat & Okhar \\
\hline Amala & Amala & Amala & Amala & Amala & Amala \\
\hline Ashuro & Amala & Ashuro & Timur & Tejpat & Okhar \\
\hline Timur & Amala & Timur & Timur & Tejpat & Okhar \\
\hline Tejpat & Amala & Tejpat & Tejpat & Tejpat & Okhar \\
\hline Okhar & Amala & Okhar & Okhar & Okhar & Okhar \\
\hline
\end{tabular}

\section{DISCUSSION}

The respondents in the household survey were mostly from the age group of 15-59 with an education level of intermediate and the sexes were nearly evenly distributed. Only $11 \%$ of the respondents were illiterate (most of the illiterate were of a higher age group) (Figure 2 and Figure 3). 


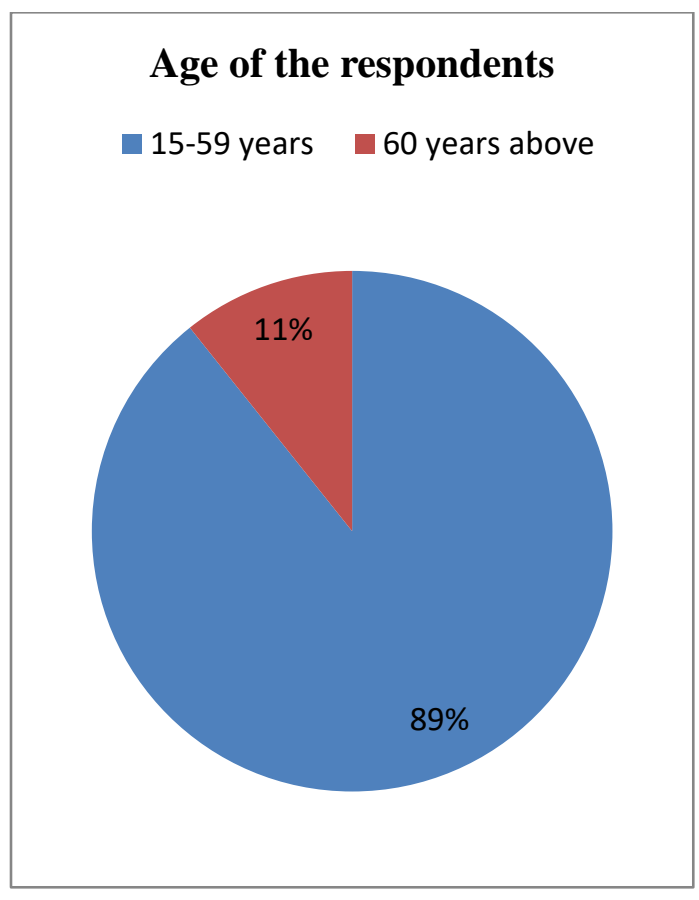

Figure 2: Age group of the respondents

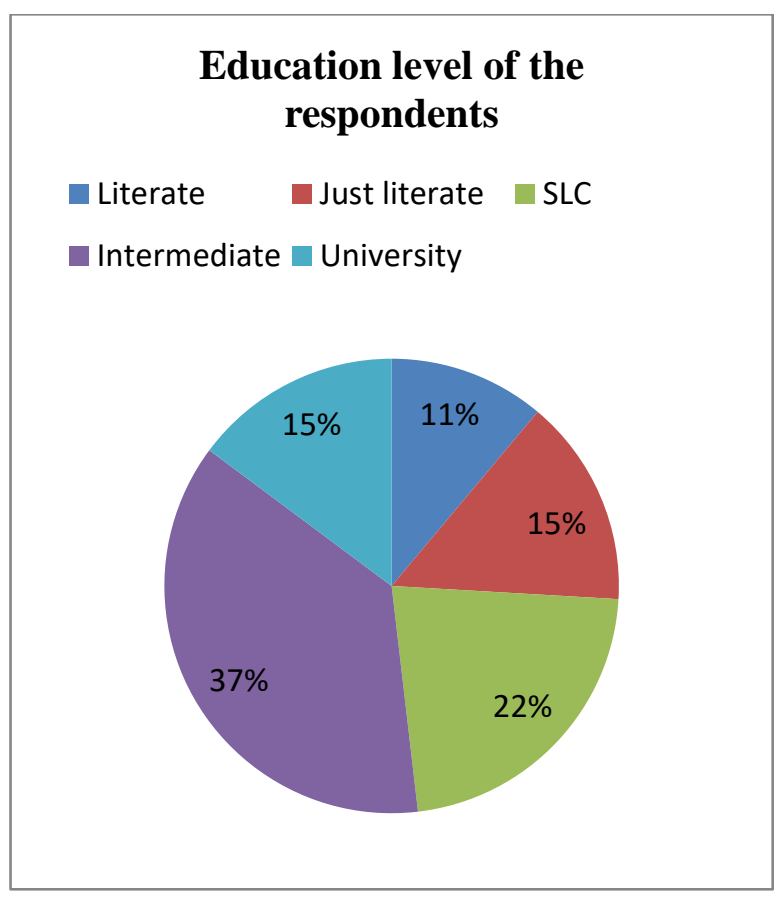

Figure 3 : Education level of the respondents

Subedi et al. (2014) have estimated at around 40,000 forest-based enterprises in Nepal and ANSAB has reported about 1,89,000 people employing in the NTFPs sub-sector drawing between 15-50\% of their household income in Nepal (Karki and Bhattarai, 2012; MSFP, 2014). But there was low rate of involvement of the respondents in the collection and sale of the NTFPs; with only five households involved in the business; no NTFPs based enterprise/industry existing in the study area. However, the respondents' participation was high in community forests and consequently, NTFPs management activities like thinning, pruning and planting among the respondents with 22 respondents responding of regular participation in such activities. Giri and Ojha (2010) reported that increased participation and empowered local institutions like CFUGs generate livelihood outcomes automatically. NEHHPA (Nepal Herbs and Herbal Products Association) has estimated about $50 \%$ of local communities involving in the collection and trade NTFPs in Nepal (Kalauni and Joshi, 2018). Among the total respondents, 59\% collect NTFPs for household purposes, $30 \%$ for selling purposes and $11 \%$ for traditional uses in the present study area (Figure 4). Maharjan and Dangal (2020) have also reported a higher number of respondents collecting NTFPs for household consumption (43\%) followed by treatment (30\%) and trade $(27 \%)$ in the Dolakha district. 


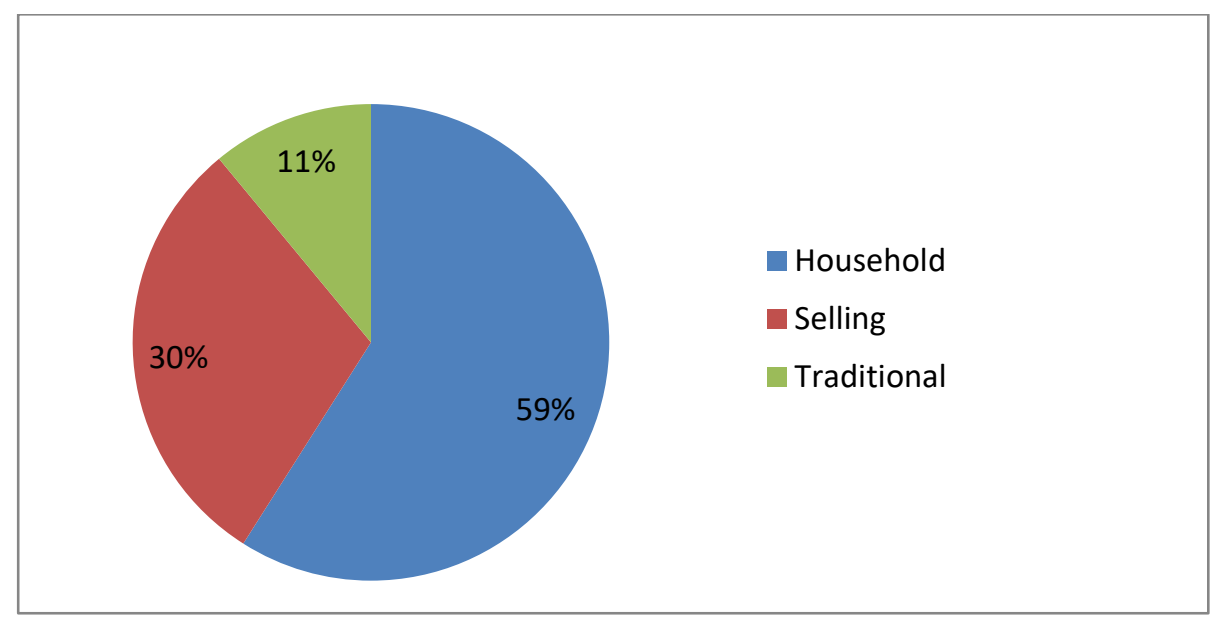

Figure 4: Purposes of NTFPs collection

Forests are sources of earnings and multiple products to people living near them (Rahut et al., 2016). In Nepal, around 143-161 types of NTFPs are collected and harvested for commercial purposes (Bhattarai and Ghimire, 2006; Subedi, 2006). In the present study, the NTFPs were used for seven different categories (purposes). Among the total 37 species of NTFPs, 24 species were used for medicine, followed by food (16 species), essential oils (three species), religious and aesthetic (two species), handicrafts (two species), dye (one species), bio-briquette (one species), adhesive (one species) and soap (one species) (Figure 5). Swertia chirayita, Rhododendron arboretum, Cinnamomun tamala, Allium wallichi, Bergenia ciliata, Berberis ariststa, Artemisia indica, etc. were used for medicine. Bauhinia variegata, Myrica esculenta, Urtica Dioca, Coriaria nepalensis, and Rubus ellipticus, etc were used for food (Table 2). The study by Kunwar et al. (2013) has recorded 132 species used for medicine out of 238 plant species recorded from far western Nepal. Our study also supports a majority of NTFPs being used for medicinal purposes. The NTFPs were represented by a total of 31 plant families, out of which Asteraceae (three species) and Poaceae (three species) represented the higher number of species, followed by Lauraceae (two species) and Urticaceae (two species). Other families were represented by a single species for each of them (Figure 6 and Table 2). 


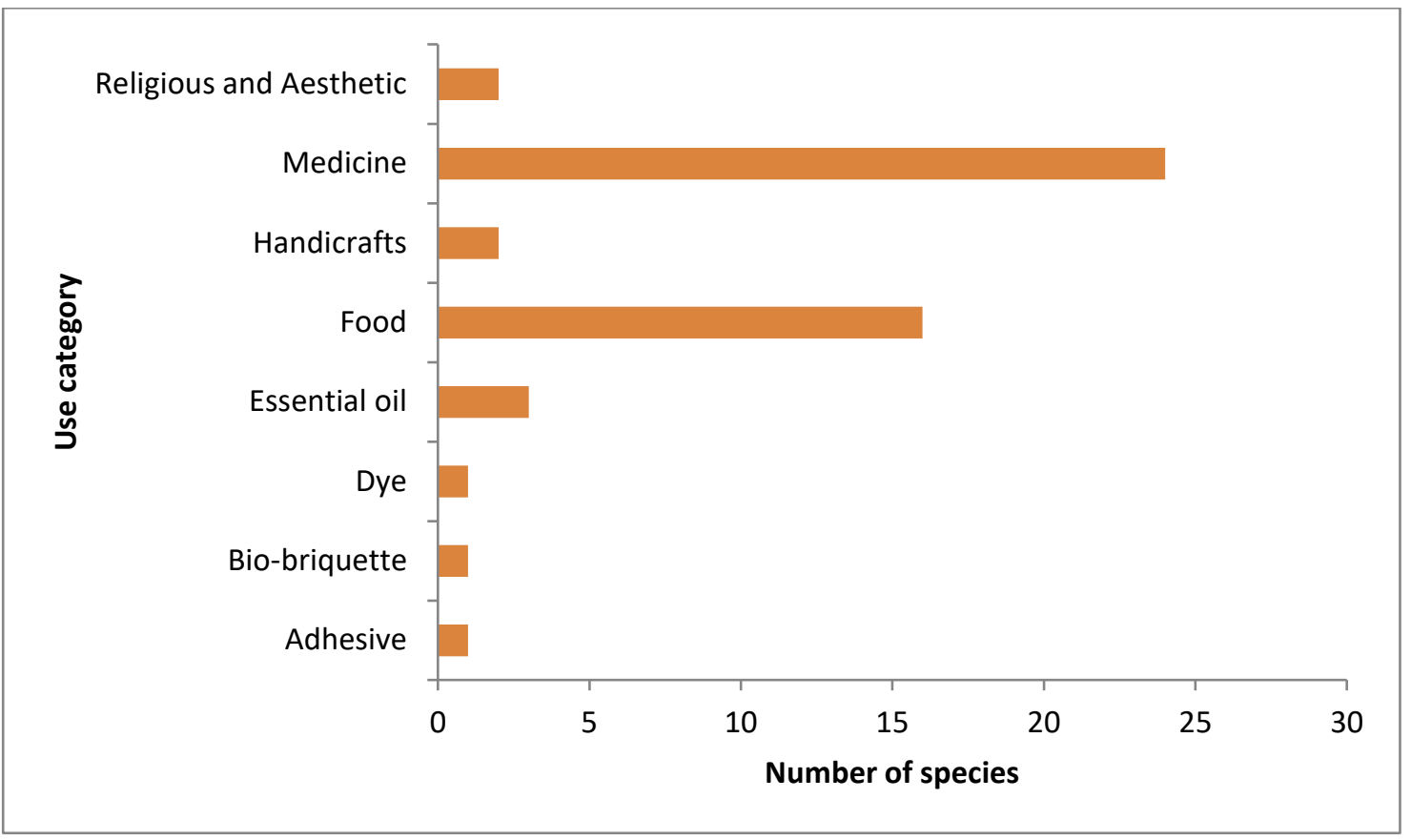

Figure 5: Use categories of NTFPs

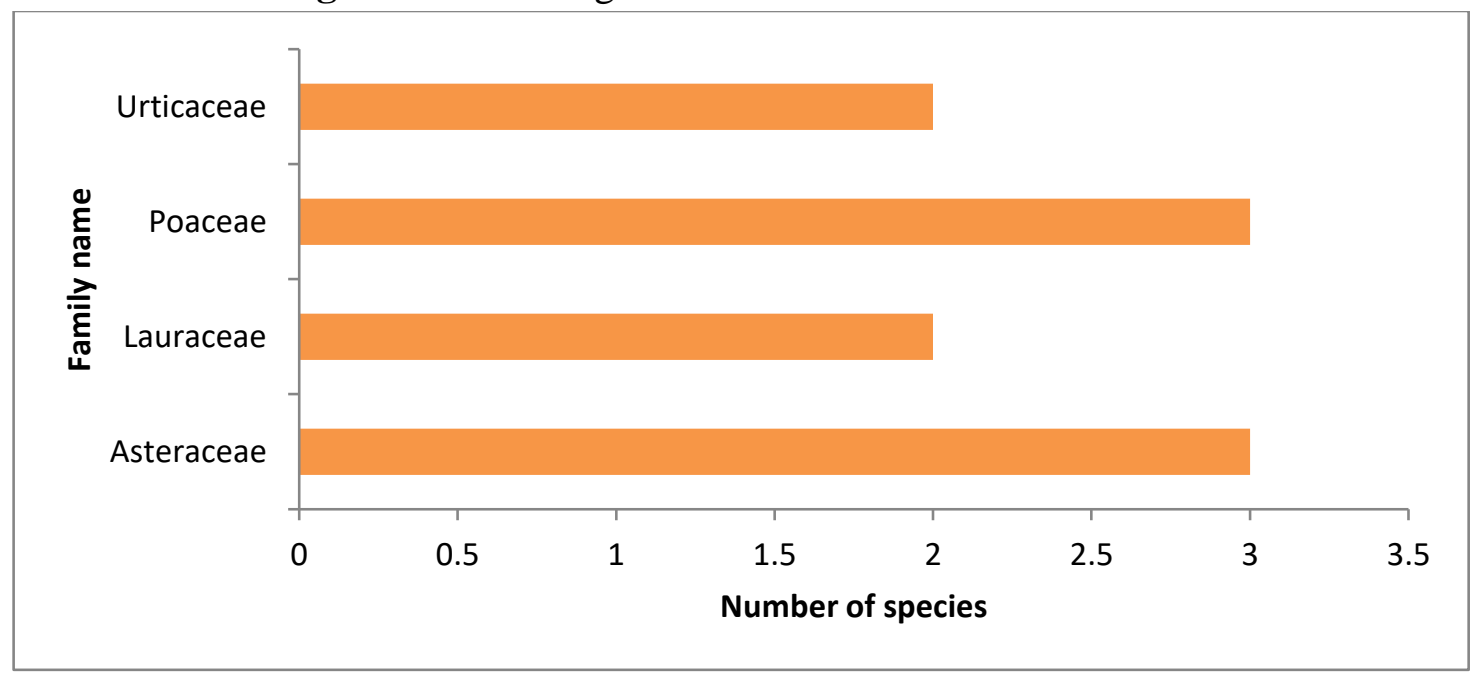

Figure 6: Family-wise species number

The potentiality of income generation from enterprises based on NTFPs was found to be medium with an average rating of top five NTFPs falling in the range of 2-2.64 as there was the medium availability of high market value NTFPs and medium diversity/distribution of other NTFPs that are marketable. The potential of NTFPs according to preference and income generation potential was highest for Juglans regia (2.64) with a slightly lower preference value of Phyllanthus emblica (2.28). Zanthoxylum armatum has a high market value (Rs. 1500-200 per $\mathrm{kg}$ ) but the locals have a higher preference for Justicia adhatoda due to its more diverse use (especially with leaves are used as green manure to increase the production of rice). Also, 
Juglans regia has a good market value (Rs. $450-500$ per $\mathrm{Kg}$ ) but due to the distant market, people extract oil from Juglans regia and use it for cooking and medicine. Cinnamomum tamala has the lowest potential (2) due to its lower availability in the area (Table 2 and Table 3). Phyllanthus emblica were collected and dried in the sunlight. The contractors come to the collectors and buy which cost Rs, 300-350 per kg. Table 4 indicates that Justica adhatoda was available more abundantly followed by Phyllanthus emblica. Phyllanthus emblica has the highest market availability and highest uses.

Although Taxus wallichiana and Rhododendron arboretum were present in high density in the forest, these were not marketed and preferred/valued by the locals due to lack of knowledge and processing technology. Phyllanthus emblica, Myrica esculenta, Rhododendron arboretum, Pinus roxburghii, Swertia chirayita, Drepanostachyum spps, Juglans regia, Zanthoxylum armatum, and Berberis ariststa have the potentiality of being the base of a small scale business from the community forest if they should be promoted and proper NTFP management practices were put in practice.

\section{CONCLUSION}

A total of 37 species of NTFPs from 31 families were recorded in the present study. The potentiality of income generation from enterprises based on NTFPs was found to be medium with an average rating of the top five NTFPs falling in the range of 2-2.64. The highest number of species were used for medicinal purposes ( 24 species) followed by food purposes (16 species). Local people were found to be dependent upon NTFPs for local use rather than their marketing and business purpose. As there were a low diversity of valuable NTFPs, then the promotion of their plantation could be promoted for future uses for income generation. Although the CFUG members and locals did use NTFPs in the area, most of them did not do all such for an income generation and there was no enterprise based on it. Promotion of such enterprises can be done through various awareness campaigns and financial incentives such as tax waivers, local financial institutions providing low amount or no collateral loans for establishing such a structural form of enterprises, etc.

\section{ACKNOWLEDGEMENTS}

We would like to thank Mr. Bishow Raj Pandit (AFO of Division Forest Office, Bajhang) for the guidance and motivation, Mr. Karna Bahadurr Khati (chief officer of DFO, Bajhang) and Ranger Mr. Kapil Rawal for the robust backing and constructive direction.

Competing interests: Authors do not have competing interests.

Funding: Authors did not get any funding for the study. 


\section{REFERENCES}

1. Ahenkan, A., \& Boon, E. (2011). Non-timber forest products farming and empowerment of rural women in Ghana. Environment, development and sustainability, 13(5), 863. https://doi.org/10.1007/s10668-011-9295-7

2. Angelsen, A., Jagger, P., Babigumira, R., Belcher, B., Hogarth, N. J., Bauch, S., ... \& Wunder, S. (2014). Environmental income and rural livelihoods: a global-comparative analysis. World Development, 64, S12-S28. https://doi.org/10.1016/j.worlddev.2014.03.006

3. Bhattarai, K. R., \& Ghimire, M. (2006). Commercially important medicinal and aromatic plants of Nepal and their distribution pattern and conservation measure along the elevation gradient of the Himalayas. Banko Janakari, 16(1), 3-13. https://doi.org/10.3126/banko.v16i1.357

4. Danekhu, U., Shrestha, R., \& Maharjan, S. R. (2018). Assessment of non timber forest products in Baghmara Buffer Zone Community Forest, Chitwan, Nepal. Journal of Natural History Museum, 30, 209-220. https://doi.org/10.3126/jnhm.v30i0.27563

5. Dhruba Bijaya, G. C., Jyoti, B., Zengrang, X., \& Can, L. (2019). Contribution of Community Forestry in Poverty Reduction: Case Study of Multiple Community Forests of Bajhang District, Nepal. Journal of Resources \& Ecology, 10(6). https://doi.org/10.5814/j.issn.1674-764x.2019.06.008

6. Edwards, D. M. (1996). The trade in non-timber forest products from Nepal. Mountain Research and Development, 16(4), 383-394. https://doi.org/10.2307/3673988

7. FAO(1991). Forest industry: Crucial for overall socio-economic development. Unsylva, 42, 16-24.

8. Gautam, D., Basnet, S., Karki, P., Thapa, B., Ojha, P., Poudel, U., ... \& Thapa, A. (2020). A review on dendrochronological potentiality of the major tree species of Nepal. Forest Research, 9(2). https://doi.org/10. 35248/2168-9776.20.9.227

9. Giri, K., \& Ojha, H. R. (2010). Enhancing livelihoods from community forestry in Nepal: can technobureaucratic behaviour allow innovation systems to work. In 9th European IFSA Symposium (pp. 4-7). http://forestaction.org

10. Giri, T. K., Bhattacharya, P., \& Santra, S. C. (2001). Ecology and economy of NTFPs in village life-A case study from Bankura District in West Bengal, India. Annales of Forestry, 9(1), 1-16. http://forestaction.org

11. GoN (Government of Nepal). (2014). Nepal National Biodiversity Strategy and Action Plan (NBSAP) (2014-2020). Ministry of Forests and Soil Conservation, Singh Durbar, Kathmandu Nepal. https://www.mofe.gov.np

12. GoN/MoFSC (1995). Forest Act, 1993 and Forest Regulation, 1995. Ministry of Forestsand Soil Conservation, Nepal. Available online: https://www.mofe.gov.np accessed on 23 February 2020. 
13. Hammet, A.L. (2004). Non-timber forest products: profits and panacea. In: A synthesis report on the current status of NTFPs in the Terai region of Nepal. MOFSC, Kathmandu. Nepal.

14. Kalauni, D., \& Joshi, A. (2018). Status of Medicinal and Aromatic Plant (MAPs) and Socio-Economic Influence in Nepalese Livelihood-A Review Research. ACTA Scientific Agriculture, 2(9), 123-130. https://www.researchgate.net/publication/328129705

15. Karki, M. B., \& Bhattarai, N. (2012). Enhancing the contribution of nontimber forest products in supporting green economy and sustainable development in mountain countries. In 2012 IUFRO Conference Division 5 Forest Products, Estoril, Lisbon, Portugal, 8-13 July 2012. Final program, proceedings and abstracts book (pp. 35-40). IUFRO (International Union of Forestry Research Organizations). https://www.cabdirect.org/cabdirect/abstract/20123419625

16. Kunwar, R. M., Mahat, L., Acharya, R. P., \& Bussmann, R. W. (2013). Medicinal plants, traditional medicine, markets and management in far-west Nepal. Journal of ethnobiology and ethnomedicine, 9(1), 1-10. https://doi.org/10.1186/1746-4269-9-24

17. Maharjan, S., \& Dangal, M. R. (2020). Economic Contribution of Non-Timber Forest Products in Rural Livelihood of Dolakha, Nepal. Open Journal for Research in Economics, 3(2). https://doi.org/10.32591/coas.ojre.0302.01055m

18. Miya, M. S., Timilsina, S., \& Chhetri, A. (2020). Ethnomedicinal uses of plants by major ethnic groups of Hilly Districts in Nepal: A review. Journal of Medicinal Botany, 4, 2437. https://doi.org/10.25081/jmb.2020.v4.6389

19. MoFSC (Ministry of Forest and Soil Conservation). (2015), Forest Policy, 2015. Ministry of Forests and Soil Conservation, Nepal. https://www.mofe.gov.np

20. MPFS. (1988). Master Plan for the Forestry Sector Nepal (MPFS). Ministry of Forests and Soil Conservation, Nepal. https://www.mofe.gov.np

21. MSFP (Multi Stakeholder Forestry Programme). (2014).Services support unit (SSU), Forestry complex, Babarmahal, Nepal. www.msfp.org.np.

22. Pyakurel, D., \& Baniya, A. (2011). NTFPs, impetus for conservation and livelihood support in Nepal. WWF Nepal. Available online: https://www.researchgate.net/publication/266402744

23. Rahut, D. B., Behera, B., \& Ali, A. (2016). Do forest resources help increase rural household income and alleviate rural poverty? Empirical evidence from Bhutan. Forests, Trees and Livelihoods, 25(3), 187-198. https://doi.org/10.1080/14728028.2016.1162754

24. Reta, Z., Adgo, Y., Girum, T., \& Mekonnen, N. (2020). Assessment of Contribution of Non-Timber Forest Products in the Socio-Economic Status of Peoples in Eastern Ethiopia. Op Acc J Bio Sci \& Res, 4(1). https://doi.org/10.46718/JBGSR.2020.04.000101

25. Shackleton, C. M., \& Pullanikkatil, D. (2019). Considering the links between non-timber forest products and poverty alleviation. In Poverty Reduction Through Non-Timber 
Forest Products (pp. 15-28). Springer, Cham. https://doi.org/10.1007/978-3-319-755809_2

26. Shrestha, S., Shrestha, J., \& Shah, K. K. (2020). Non-Timber Forest Products and their Role in the Livelihoods of People of Nepal: A Critical Review. Grassroots Journal of Natural Resources, 3(2), 42-56. https://doi.org/10.33002/nr2581.6853.03024

27. Sing, N. B., Khanal, D., \& Bhandari, L. (2020). Yarsagumba Collection Trend and its Impact on Livelihood of People of Bajhang District in the Context of Climate Change. The Geographic Base, 7, 65-78. https://doi.org/10.3126/tgb.v7i0.34272

28. Subedi, B. P. (2006). Linking plant-based enterprises and local communities to biodiversity conservation in Nepal Himalaya. Akhil Book Distributors.

29. Subedi, B.P., Ghimire, P.L., Koontz, A., Khanal, S.C., Katwal, P., Sthapit, K.R. and Mishra, S.K. (2014). Private Sector Involvement and Investment in Nepal's Forestry: Status, Prospects and Way Forward. Multi-Stakeholder Forestry Programme (MSFP)Service Support Unit, Babarmahal, Kathmandu, Nepal.

30. Thakur, R. B. (2005) Assessment of non timber forest products for enterprise development (a case study from government managed forest of hosrandi and uram Pokhara VDCs of Parvat district). B.Sc. thesis, Institute of Forestry, Tribhuvan University, Pokhara, Nepal. https://www.academia.edu/5935380

31. Timilsina, S., Bhattarai, R., Miya, M., \& Gautam, D. (2020). Sissoo, its Pathogenic Constraints and their Management in Nepal: A review. Grassroots Journal of Natural Resources, 3, 1-17. https://doi.org/10.33002/nr2581.6853.03041 
International Research Journal of MMC (IRJMMC)

Vol. 2 Issue 2 (June, 2021)

ISSN 2717-4999 (Online)

$2717-4980$ (Print) 